\title{
They Went to England, Liked it, so Stayed
}

ARCH. C. BUDD, Swift Current

In some of the slowly moving streams in the Souris River area of South-eastern Saskatchewan, the Canadian Water-weed or Waterthyme may be found. This entirely aquatic plant has long branching stems with leaves about a quarter to half an inch long, less than an eighth of an inch wide, and borne in whorls of threes or rarely fours. These plants are dioecious, that is the male and female flowers are on different plants, but they increase vegetatively and any piece of stem bearing a whorl of leaves will grow very rapidly. Botanists call it Anacharis canadensis, Elodea canadensis or Philotria canadensis, just take your choice, but I like to call it Anacharis as I did when a boy.

In the early 1850's it is said that a piece of Canadian Water-weed fell into the Thames. in England from the Botanical Gardens at Oxford and that by 1866 it had so increased that some parts of the river were almost unnavigable. Other reports say it was first noticed about 1842 and was called "Babington's Curse" after the man who was wrongly supposed to have first brought it in to England. Although only the pistillate or female plant is found over there, thus necessitating its spread entirely vegetatively, nevertheless before I left England in 1910 many canals and small streams were entirely choked with the weed. Many water-mills had their mill-ponds so choked that they were unable to function, and it was the chief aquatic plant in most small ponds. Anacharis makes a splendid oxygenating plant in our aquariums and is apparently a good food plant for our aquatic life as well as for ducks and swans, but it was an expensive weed for Britain.

Growing in water, on the banks of running streams and along the lake shores of the Cypress Hills, we find a lovely, showy plant called the Yellow Monkey Flower, Mimulus guttatus. It has round to lanceolate, much toothed, opposite leaves and grows from six to eighteen inches high and bears conspicuous flowers from one to one and one-half inches long, of the snapdragon type, bright yellow with reddish spots near the centre. This handsome plant was first cultivated in England in most flower gardens but found climatic conditions agreeable and escaped into the streams and rivers. This fairly recent addition to the British flora, although very common now, is hardly likely to become such a nuisance as the Canadian Waterweed.

\section{Familiar Wild Flowers}

\section{By B. DeVRIES, Fort Qu'Appelle}

Dear' Fellow Naturalists:

We are citizens of the comparatively young province of Saskatchewan which in its vast expanse harbours still an abundant wealth of native Flora and Fauna threatened by the steady advance of Civilization. This advance is necessary for the growth of our province, but destructive in its way. Many wild plants face partial or even total destruction. Therefore, I thought it might be worth while to write four quarterly articles about our best known wild flowers. As subjects I have chosen: Crocus Anemone; Western Red Lily; Rose; Goldenrod.
These flowers seem to me the most striking. I hope these articles will give us a deeper understanding of our native plants botanically, and that they will show us the importance of protecting them. Once we have become more familiar with these plants through written articles, slides or films, we can help to ensure their protection by establishing Wild Flower Sanctuaries. The Regina Natural History Society already possesses one called "Hidden Valley" near Craven, Saskatchewan. It is badly neglected, but restorable (Members, what about this?). There are also a few privately-owned sanc- 
tuaries throughout the province. However, there should be more if we are to enjoy our wild flower heritage for all time. We naturalists know the rewarding experience obtained from close contact with nature, so we must lead the way in any conservation project.

\section{No. 1 Crocus Anemone PULSATILLA LUDOVICIANA}

(Nutt.) Heller

This well known spring flower of our prairies is a genus of the Buttercup or Crowfoot family (Ranunculaceae) - a family of Dicotyledons belonging to the series Ranales and containing 10 genera, divided into 40 species. Formerly this plant was classified a species of the genus Anemone as Anemone patens L. var. Wolfgangiana (Bess.) Koch. Later on it was re-classified under the genus Pulsatilla as Pulsatilla ludoviciana (Nutt.) Heller. The Crocus Anemone is commonly called Prairie Crocus, as if it were a crocus. Such is not the case, as a crocus belongs to a totally different botanical family - the Iris family (Iridaceae) which differs distinctly from the Ranunculaceae. Another com m o $\mathrm{m}$ name is Pasque Flower, presumably derived from the root word Pasch (Hebrew word pisach, meaning passover). No doubt it got this name first because it blooms around Easter. The Crocus Anemone is a perennial herb appearing each Spring from a thick woody taproot firmly anchored in the soil. With the first warm rays of the sun the violetpurple (occasionally white) flowers are pushed up before the leaves. The flower stalk is short at first but gradually becomes longer; it is erect in form and covered with silky hairs. This slowness in growth could be due to a climatic condition such as cool days with sudden temperature drops. The plants being short and covered with these silky hairs are able to protect themselves by absorbing what warmth they may receive and by keeping this imprisoned in their covering. Later, as the temperature rises, this protection seems less necessary and the flower stalk grows taller, often up to ten inches. Pollination also seems to profit from this slow growth. The flowers are

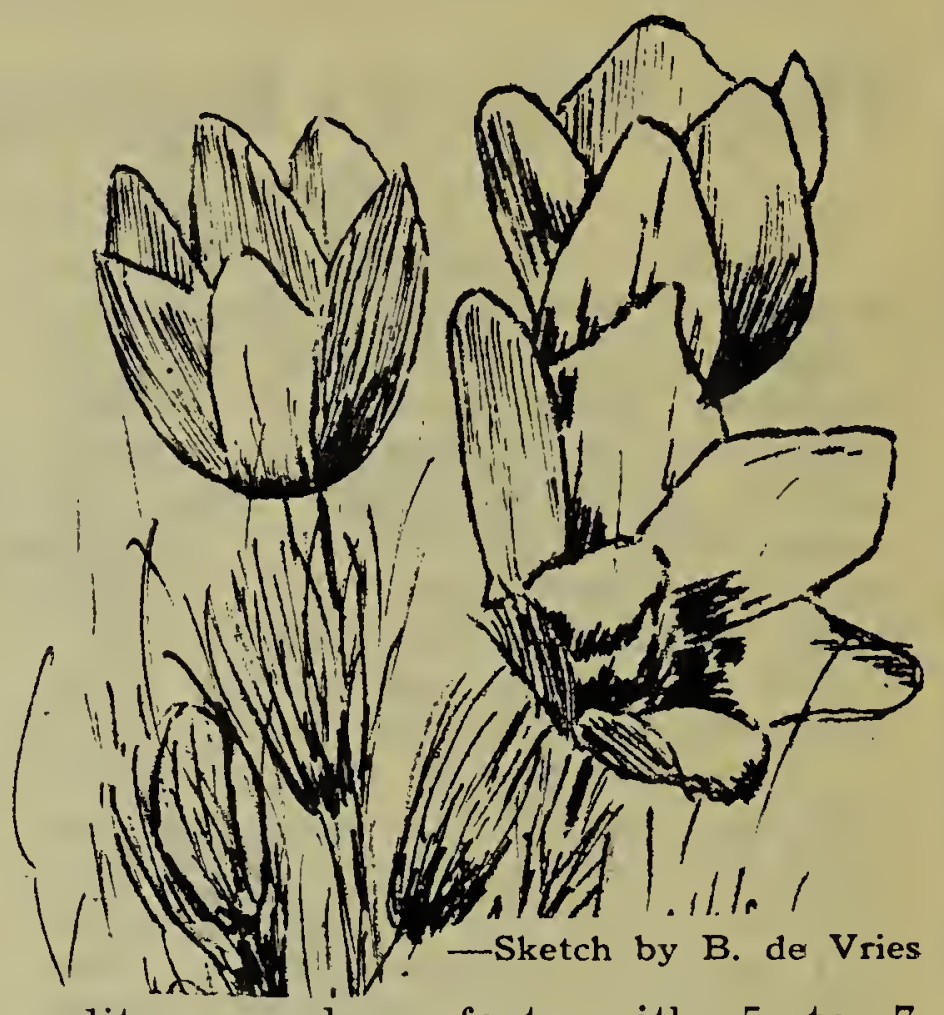

solitary and perfect, with 5 to 7 petaloid sepals, followed by numercus stamens with numerous superior carpels. The sepals and stamens are hypogynous. The fruiting stems are tall, bearing many achenes with long, feathery styles. This aids in dissemination and gives the plants a gay attire during the fruiting period. After flowering, the deeplydivided leaves are borne on rather long stalks and covered with silky hairs. The involucral leaves are also divided but have no stalks. The Crocus Anemone is a common plant throughout the prairie region, favoring overgrazed land and a fairly dry soil. It has a slight toxic effect on livestock. We will find this species westward through Alberta to British Columbia where it is replaced by the species Anemone occidentalis which grows on mountain slopes. Close relatives of the Crocus Anemone are: Delphinium (Larkspur), Aquilegia (Columbine), Ranunculus (Buttercup), Anemone (Anemone). This relationship is to be seen in the deeply cleft leaves, the floral number 5 , the fact that the fruits are often achenes. As a convenient method of expressing an arrangement of flower parts, a Floral Formula has been derived in phonetic form. Whorls are represented by the letters $\mathbf{S}$ (sepals), $\mathrm{P}$ (petals), A (stamens), C (carpels); a figure follows each letter to indicate the number of parts in each whorl. Thus, the Flower Formula for a 5 petaloid Crocus Anemone is as follows: S5 $A * C *$ (* indicated indefinite and - under a letter indicated superior). 